\title{
The Use of Social Media at State Islamic Colleges
}

\author{
Muhammad Munadi \\ IAIN Surakarta \\ munadimahdiputra@gmail.com
}

\begin{abstract}
This study aims to determine the management of social media, the trend of followers of each social media, as well as the use of social media in universities under the Ministry of Religion Affairs, especially in the area of the island of Java. This study used content analysis research with data derived from the website, documents that can be downloaded from the website relating to social media university activities and its development. Social media used as research are all types of social media used by IAIN Ponorogo, IAIN Surakarta, IAIN Kudus, IAIN Pekalongan, IAIN Salatiga, UIN Walisongo Semarang, and IAIN Ponorogo. Data analysis used interactive analysis and descriptive statistical analysis. The results showed that the management of social media is in the Public Relations and Publications sub-section of each PTKI with one admin operating on each social media made. the most followers on Instagram social media are IAIN Salatiga. For social media youtube is IAIN Ponorogo, while the most Twitter follower IAIN Surakarta and Facebook followers the most is IAIN Pekalongan. The use of diverse social media, on Instagram for academic activities including promotion for prospective new students dominant in all research locations and balanced with greeting content of national and religious activities by $83.3 \%$, for YouTube by $66.6 \%$ dominant content of academic activities and this is the same as what happened to the Twitter, while on social media Facebook a percentage of $66.6 \%$ in the content of academic activities and balanced with the greeting content of national and religious activities. The development of social media content lies in quoting national and religious activities Utilization of social media can be used for all higher education service activities within the scope of the tri dharma of higher education, both the dharma of education/teaching, research, and community service.
\end{abstract}

Keywords: Social Media, Management, Islamic Higher Education, Academic, Greeting

Abstrak: Kajian ini bertujuan untuk mengetabui pengelolaan media sosial, trend follower masing-masing media sosial, serta pemanfaatan media sosial pada perguruan tinggi di bawah Kementerian Agama terutama di daerah tengah pulau Jawa. Penelitian ini menggunakan penelitian konten analisis dengan data berasal dari website, dokumen-dokumen yang bisa diunduh dari website berkaitan dengan media sosial kegiatan perguruan tinggi sertq pengembangannya. Media sosial yang dijadikan penelitian adalah semua jenis media sosial yang dipakai IAIN Ponorogo, IAIN Surakarta, IAIN Kudus, IAIN Pekalongan, IAIN Salatiga, UIN Walisongo Semarang, serta LAIN Ponorogo. Data dianalisis dengan menggunakan interaktif dan statistik deskriptif. Penelitian ini menemukan bahwa pengelolaan media sosial berada pada sub bagian Humas dan Publikasi pada masing-masing PTKI dengan dioperasionalkan satu orang admin pada masing-masing media sosial yang dibuat. follower paling banyak pada media sosial Instagram adalah LAIN Salatiga. Untuk media sosial youtube adalah IAIN Ponorogo, sedangkan follower Twiter paling banyak. IAIN Surakarta serta Follower Facebook paling banyak adalah LAIN Pekalongan. Pemanfaatan media sosial beragam, pada Instagram untuk kegiatan akademik termasuk di dalamnya promosi bagi calon mahasiswa baru dominan terjadi di semua lokasi penelitian dan seimbang dengan muatan greeting kegiatan nasional dan agama 
sebesar $83,3 \%$, untuk youtube sebesar 66,6\% dominan muatan kegiatan akademik dan ini sama dengan yang terjadi pada twiter, sedangkan pada media sosial facebook prosentase sebesar 66,6\% pada muatan kegiatan akademik dan seimbang dengan muatan greeting kegiatan nasional dan agama. Pengembangan muatan media sosial terletak pada quote kegiatan nasional dan agama. Pemanfaatan media social bisa dipakai untuk selurub kegiatan layanan perguruan tinggi dalam cakupan tri dharma perguruan tinggi baik dharma pendidikan/pengajaran, penelitian serta pengabdian kepada masyarakat.

Kata Kunci: Media Sosial, Manajemen, Pendidikan Tinggi Islam, Akademik, Ucapan

\section{INTRODUCTION}

The use of the internet and its facilities is increasing day by day. According to data from the Association of Indonesian Internet Service Providers (APJII) shows that there are 171.17 million internet users in Indonesia as of April 2019 out of a total population of 264 million (Pratomo, 2019). According to the Secretary General of APJII, Henri Kasyfi Soemartono, its users are: (Haryanto, 2019) in the age range of 15-19 years which reached 91\%. Of the number of internet users in Indonesia, 88 percent actively access YouTube. WhatsApp is the second most accessed social media with users reaching 83 percent. While Facebook is in third position with $81 \%$ users and Instagram users are in fourth position with 80 percent (Public Relations of the Ministry of Administrative and Bureaucratic Reform, 2019). (Parusheva et al., 2018:171) stated that social media is very popular among young people, including those attending universities and higher education institutions. This is reinforced by the opinion of Gruber quoted (Falahah \& Rosmala, 2012:157-158) that because social networking has become one of the most popular communication tools among college-age students, universities are starting to use this technology to communicate with current and prospective students. The two statements correspond to data from Global WebIndex 2019 (Duarte, 2019) shows that People aged 16-24 spent the most time on social media in 2018 with a daily average in 2018 of 175 minutes for this age group globally. This condition needs to be used by universities to help improve their image (Republika, 28 November 2014), for means of communication and socialization of higher education programs and activities (Unimalnews, 2019), as well as means of diplomacy, branding, and internal communication (UNY, 2019). Universities that use social media Facebook, Instagram, and Twitter as media for publication simultaneously are more popular because they have a larger number of followers, are more active in using social media, are more active in sharing posts, are more active in replying to audience comments, and use image media more to post as well as more types of informational content (Mardhiyyah, 2017:71-72). Another finding shows that social media is used as a teaching aid in higher education in the Indian state of Tamil Nadu (Vivakaran \& Neelamalar, 2018), online social media used for collaborative learning has a significant 
impact on interactivity with peers, teachers, and online knowledge sharing behavior. (Ansari \& Khan, 2020), as well as contributing positively to increasing knowledge sharing individually and collectively in the higher education community (Aldahdouh et al., 2020). These opinions and findings strengthen the statement (Chugh, 2020) that the unusually high use of social media makes it suitable for administrators, managers, students, and teachers/lecturers in higher education institutions.

Once the importance of social media for universities, the Ministry of Research, Technology and Higher Education held a breakthrough in the Public Relations Award for PTN and Kopertis starting in 2017. This activity has website, publicity, and social media categories. All three relate to the quality of information services. For the social media category the assessment indicators indicator covering social media management, verified accounts, including diversification of social media types (Facebook, Twitter, Instagram, YouTube) with assessment components covering aspects of updating information and interactivity (LLDIKTI V, 2018).

Social media defined Merriam-Webster's Dictionary online (MerriamWebster, 2021) as a form of electronic communication (such as websites for social networking and micro blogging) in which users create online communities to share information, ideas, private messages and other content (such as videos). This understanding means that social media is a form of electronic communication that can create online communities to share information, ideas, personal messages, and other content (such as videos). Operational definition stated (Maya Dollarhide, 2021) defines social media as a computer-based technology that facilitates the exchange of ideas, thoughts, and information through the construction of networks and virtual communities. A more concrete understanding is expressed by Curtis who is quoted (Dan V. Dao, 2015:85) states "Social media are Internet sites where people interact freely, sharing and discussing information about each other and their lives, using a multimedia mix of personal words, pictures, videos and audio". This understanding shows that social media is a place where people interact freely, share and discuss information about each other and their lives, using a multimedia mix of personal words, images, videos and audio through the internet.

These three definitions show that social media has the following characteristics:

1. Internet based

2. Fast electronic content communication.

3. Free interaction 
4. Share and discuss

5. Socialization and networking

6. Content relates to personal information, words, documents, audio, video, and photos.

The above characteristics are in accordance with the statement (Philip N. Howard; Malcolm R. Parks, 2012) that social media consists of information infrastructure and tools used to produce and distribute content that has individual value but reflects shared values, content that takes digital form from personal messages, news, ideas, which become cultural products; the people, organizations, and industries that produce and consume tools and content.

Some of these definitions and characteristics confirm the statement (Reuben, 2008:1) that social media redefining the way one relates to others as human beings and the way one as human beings relates to organizations that serve other human beings. This means dialogue - a two-way discussion that brings people together to find and share information. Thus making interesting what is stated (Penn, 2017) about social media provides strength in the form of friends, colleagues and family: people with whom you have a relationship and whose opinions matter to you, closeness - both temporarily and virtually: the people you connect with are never far from your mobile device, and provide great opportunity for the number of people in the influencing group.

The function of social media for universities according to (Digital Marketing Institute Daily Digest, 2020) is:

1. Increasing Student Engagement

2. Increase Brand Awareness

3. Encouraging Number of Registrations

The benefits are extended (Sehl, 2020) as follows:

1. Student recruitment

2. Alumni and student engagement

3. Effective School Promotion

4. Crisis Communication

These benefits show that social media can be an effective and efficient digital marketing medium compared to traditional marketing. Based on the explanation above, it can be concluded that various reasons for using social media in higher education can be stated as follows: students and college students spend more time on the internet, market share uses the internet to find / select educational institutions, parents have started to conduct school assessments or college based on its website and online presence, and students/students explore and compare institutions based on their online presence. 


\section{RESEARCH METHODS}

This study uses content analysis research with data derived from documents (photos, written content, other documents related to research) that have been uploaded and can be downloaded from social media related to higher education activities and their development. The time of the research was early May - June 2020. The social media used for the research were all types of social media used by PTKIN Central Java plus 1 PTKIN East Java and 1 PTKIN East Java West. The description is as follows:

Table 1

Social Media Ownership at PTKIN

\begin{tabular}{lcccc}
\hline \multirow{2}{*}{ PTKIN } & \multicolumn{4}{c}{ Social Media Communicated on PT. Website } \\
\cline { 2 - 5 } & Instagram & Youtube & Twitter & Facebook \\
\hline IAIN Ponorogo & $\mathrm{V}$ & $\mathrm{V}$ & $\mathrm{V}$ & $\mathrm{V}$ \\
\hline IAIN Salatiga & $\mathrm{V}$ & $\mathrm{V}$ & $\mathrm{V}$ & $\mathrm{V}$ \\
\hline IAIN Cirebon & - & - & - & - \\
\hline IAIN Surakarta & $\mathrm{V}$ & - & $\mathrm{V}$ & $\mathrm{V}$ \\
\hline IAIN Purwokerto & - & - & - & - \\
\hline IAIN Pekalongan & $\mathrm{V}$ & $\mathrm{V}$ & $\mathrm{V}$ & $\mathrm{V}$ \\
\hline IAIN Kudus & $\mathrm{V}$ & - & $\mathrm{V}$ & - \\
\hline UIN Walisongo & - & $\mathrm{V}$ & $\mathrm{V}$ & $\mathrm{V}$
\end{tabular}

All of these PTKIN will be reviewed with 3 considerations, namely using social media, being informed of the type on the main university website and using at least 3 media. With these considerations, PTKIN was chosen as follows:

Table 2

Research Subject

\begin{tabular}{lcccc}
\hline \multirow{2}{*}{ PTKIN } & \multicolumn{4}{c}{ Social Media Communicated on PT . Website } \\
\cline { 2 - 5 } & Instagram & Youtube & Twitter & Facebook \\
\hline IAIN Ponorogo & $\mathrm{V}$ & $\mathrm{V}$ & $\mathrm{V}$ & $\mathrm{V}$ \\
\hline IAIN Salatiga & $\mathrm{V}$ & $\mathrm{V}$ & $\mathrm{V}$ & $\mathrm{V}$ \\
\hline IAIN Surakarta & $\mathrm{V}$ & - & $\mathrm{V}$ & $\mathrm{V}$ \\
\hline
\end{tabular}




\begin{tabular}{lllll}
\hline IAIN Pekalongan & $\mathrm{V}$ & $\mathrm{V}$ & $\mathrm{V}$ & $\mathrm{V}$ \\
\hline IAIN Kudus & $\mathrm{V}$ & - & $\mathrm{V}$ & - \\
\hline UIN Walisongo & - & $\mathrm{V}$ & $\mathrm{V}$ & $\mathrm{V}$
\end{tabular}

The two PTKIN that were not used as research subjects, if they were tracked manually on the internet, actually have these 4 social media. However, because it was not communicated on the PTKIN website, it was not the subject of this research.

The validity of the data by using triangulation methods by validating the data contained in documents on social media with online interviews with media managers at each PTKIN studied, in addition to validating between social media in PTKIN. Data were analyzed using interactive analysis and descriptive statistics.

\section{RESULTS AND DISCUSSION}

\section{Social Media Management at PTKIN}

The social media management structure is in the Public Relations subsection of each PTKIN. The head of the Public Relations sub-section appointed a number of operators as admits for each of the social media created. Even though there is already one admin and one social media, the budget for activities cannot be allocated from the institution. This is in conflict with the PMK regulation which only mentions the Honorarium for the Website Management Team (Minister of Finance, 2019:15 and 17). The statement is also limited to websites managed by echelon I/equivalent units or websites managed by vertical units at the echelon II level, which is given an honorarium for the website management team. The honorarium is also limited to: person in charge, editors, editors, web admits, web developers, and article makers. However, from the online questionnaire distributed, the admits still provide daily updates on managed social media. It can be seen from this enthusiasm that PTKIN can be like a finding (Maresova \& Hruska, 2020:1) that all of the studied universities upload a post at least once per day. Managing social media is not easy because it involves technology, humans and operates within the boundaries and hierarchies of the physical world (Gruzd, 2015).

\section{Instagram Management}

The six PTKIN that were used as research locations turned out to be 5 that had an Instagram that was actively managed and only one did not have an Instagram account. PTKIN which is the subject of the study has an Instagram with the following address: 
Table 3

Ownership of Instagram on PTKIN

\begin{tabular}{llc}
\hline \multicolumn{1}{c}{ PTKIN } & \multicolumn{1}{c}{ Instagram } & Information \\
\hline IAIN Ponorogo & $\begin{array}{l}\text { https://www.instagram.com/iain. } \\
\text { ponorogo/ }\end{array}$ & Active \\
\hline IAIN Salatiga & $\begin{array}{l}\text { https://www.instagram.com/iain } \\
\text { _salatiga/ }\end{array}$ & Active \\
& $\begin{array}{l}\text { https://www.instagram.com/iain. } \\
\text { surakarta/ }\end{array}$ & Active \\
\hline IAIN Surakarta & Active \\
\hline IAIN Pekalongan & $\begin{array}{l}\text { htps://www.instagram.com/iain } \\
\text { _pekalongan/ }\end{array}$ & \\
\hline IAIN Kudus & $\begin{array}{l}\text { https://www.instagram.com/iain } \\
\text { _kudus/ }\end{array}$ & Active \\
\hline
\end{tabular}

UIN Walisongo

The entire PTKIN that was used as a research site that did not have an Instagram account was UIN Walisongo Semarang so that it had an impact on the number of followers and the number of posts. The following table can be seen as follows:

\section{Table 4}

Number of Posts, Followers, and Followings on Instagram at PTKIN

\begin{tabular}{lccc}
\hline \multirow{2}{*}{ PTKIN } & \multicolumn{3}{c}{ Instagram } \\
\cline { 2 - 4 } & Posts & Followers & Follow \\
\hline IAIN Ponorogo & 277 & 4768 & 113 \\
\hline IAIN Salatiga & 602 & 17500 & 109 \\
\hline IAIN Surakarta & 599 & 15800 & 766 \\
\hline IAIN Pekalongan & 292 & 13000 & 39 \\
\hline IAIN Kudus & 198 & 8209 & 217 \\
\hline UIN Walisongo & - & - & -
\end{tabular}

The highest number of followers occurred at IAIN Salatiga. The number of followers is 17500 people. This is in line with the number that is posted to Instagram. The data above when compared to followers with other social media used by PTKIN looks the most popular is Instagram. This is in line with the 
findings (Motta \& Barbosa, 2018:126) that Instagram, and Twitter. G+ is quite popular in the United States and is also attracting more followers.

A large number of followers can be validated for their content content through the following table:

Table 5

Instagram load on PTKIN

\begin{tabular}{lcccc}
\hline \multirow{2}{*}{ PTKIN } & \multicolumn{5}{c}{ Instagram material } \\
\cline { 2 - 5 } & $\begin{array}{c}\text { Academic } \\
\text { Activities }\end{array}$ & $\begin{array}{c}\text { Bureaucratic } \\
\text { and Non- } \\
\text { Academic } \\
\text { Activities }\end{array}$ & $\begin{array}{c}\text { Speeches of } \\
\text { National } \\
\text { and } \\
\text { Religious } \\
\text { Activities }\end{array}$ & $\begin{array}{c}\text { Quotes for } \\
\text { National } \\
\text { and } \\
\text { Religious } \\
\text { Activities }\end{array}$ \\
\hline IAIN Ponorogo & $\mathrm{V}$ & $\mathrm{V}$ & $\mathrm{V}$ & - \\
\hline IAIN Salatiga & $\mathrm{V}$ & $\mathrm{V}$ & $\mathrm{V}$ & $\mathrm{V}$ \\
\hline IAIN Surakarta & $\mathrm{V}$ & - & $\mathrm{V}$ & - \\
\hline IAIN & $\mathrm{V}$ & - & $\mathrm{V}$ & - \\
Pekalongan & $\mathrm{V}$ & - & $\mathrm{V}$ & $\mathrm{V}$ \\
\hline IAIN Kudus & - & - & - & - \\
\hline UIN Walisongo & $83.3 \%$ & $33.3 \%$ & $83.3 \%$ & $33.3 \%$ \\
\hline Percentage & & & & \\
\hline
\end{tabular}

The table above shows that the high position at IAIN Salatiga is due to the most Instagram material compared to other PTKIN. Four and more diverse materials on Instagram at IAIN Salatiga compared to other PTKIN.

\section{Instagram Management}

The next medium is Youtube. The description is as follows:

Table 6

Youtube ownership of PTKIN

\begin{tabular}{cl}
\hline \multicolumn{1}{c}{ PTKIN } & \multicolumn{1}{c}{ Youtube } \\
\hline IAIN Ponorogo & $\begin{array}{l}\text { https://www.youtube.com/channel/UCzz4zcM8 } \\
\text { wZCDpHI3DbCENqA }\end{array}$ \\
\hline IAIN Salatiga & $\begin{array}{l}\text { https://www.youtube.com/channel/UCFzeQ8bq7jbz } \\
\text { 7EPNrasCrdQ }\end{array}$ \\
\hline
\end{tabular}




\begin{tabular}{ll}
\hline IAIN Surakarta & - \\
\hline IAIN Pekalongan & $\begin{array}{l}\text { https://www.youtube.com/user/STAINPekalongan/ } \\
\text { videos }\end{array}$ \\
\hline IAIN Kudus & - \\
\hline UIN Walisongo & $\begin{array}{l}\text { https://www.youtube.com/channel/UCDZnbMThn } \\
\text { FPiKkUieFH_Ttg }\end{array}$
\end{tabular}

The table above shows that the research subjects who do not have a youtube account are IAIN Surakarta and IAIN Kudus. This has an impact on the number of subscribers. The following table shows the number of subscribers.

Table 7

Number of Youtube Subscribers on PTKIN

\begin{tabular}{lc}
\hline \multicolumn{1}{c}{ PTKIN } & Subscriber \\
\hline IAIN Ponorogo & 4134 \\
\hline IAIN Salatiga & 1430 \\
\hline IAIN Surakarta & - \\
\hline IAIN Pekalongan & 887 \\
\hline IAIN Kudus & - \\
\hline UIN Walisongo & 2150
\end{tabular}

Optimizing PTKIN in managing YouTube social media so that it can increase the number of followers as well as young people as a potential market share to become new students. It is based on opinion (Bennett, 2021) that YouTube has 1.5 billion users accessing content, making it the second most popular platform among young people. How to increase followers can follow Jackman's (2019) findings that YouTube is a means for summarizing subject/lecture content, clarifying complex concepts, and concretizing abstract ideas. Besides that, it makes it easier for students to get new skills development (Iftikhar et al., 2020).

Table 8

Youtube material on PTKIN

\begin{tabular}{ccccc}
\hline \multirow{3}{*}{ PTKIN } & \multicolumn{4}{c}{ Youtube material } \\
\cline { 2 - 5 } & $\begin{array}{c}\text { Academic } \\
\text { Activities }\end{array}$ & $\begin{array}{c}\text { Bureaucratic } \\
\text { and Non- }\end{array}$ & $\begin{array}{c}\text { Speeches of } \\
\text { National and }\end{array}$ & $\begin{array}{c}\text { Quotes for } \\
\text { National }\end{array}$ \\
\hline
\end{tabular}




\begin{tabular}{lcccc}
\hline & Academic & Religious \\
Activities & Activities & $\begin{array}{c}\text { and } \\
\text { Religious } \\
\text { Activities }\end{array}$ \\
\hline IAIN Ponorogo & - & $\mathrm{V}$ & - & - \\
\hline IAIN Salatiga & $\mathrm{V}$ & - & $\mathrm{V}$ & This thing \\
\hline IAIN Surakarta & - & - & - & - \\
\hline IAIN Pekalongan & $\mathrm{V}$ & - & - & - \\
\hline IAIN Kudus & $\mathrm{V}$ & - & $\mathrm{V}$ & - \\
\hline UIN Walisongo & $\mathrm{V}$ & - & - & $0 \%$ \\
\hline Percentage & $66.6 \%$ & $16.6 \%$ & $33.3 \%$ & - \\
\hline
\end{tabular}

The use of YouTube from the content on PTKIN is less touching on the side of the picture that is on campus. This is in contrast to the findings of Barnes and Mattson quoted (Bado \& Nyangau, 2017:47) that some universities use videos uploaded on YouTube to provide virtual campus tours or just to show off lecture halls or sample lecture halls.

The number of followers is not affected by the length of time the institution has joined social media. The following table can be seen below.

Table 9

Time to Join Youtube on PTKIN

\begin{tabular}{lc}
\hline \multicolumn{1}{c}{ PTKIN } & Joined \\
\hline IAIN Ponorogo & January 20, 2016 \\
\hline IAIN Salatiga & February 20, 2019 \\
\hline IAIN Surakarta & - \\
\hline IAIN Pekalongan & 12 July 2012 \\
\hline IAIN Kudus & - \\
\hline UIN Walisongo & March 6, 2017 \\
\hline
\end{tabular}

The table above shows that the longest joining is IAIN Pekalongan. Although it has been since 2012 it doesn't automatically have a large number of followers. Even if you look at the larger followers of IAIN Ponorogo who joined YouTube only in 2016. 


\section{Twitter Management}

Twitter is owned by all PTKIN who are used as research subjects. The description is as follows:

\section{Table 10}

Ownership of Instagram on PTKIN

\begin{tabular}{llc}
\hline \multicolumn{1}{c}{ PTKIN } & \multicolumn{1}{c}{ Twitter } & Information \\
\hline IAIN Ponorogo & $\underline{\text { https://twitter.com/Ponorogo IAIN }}$ & Active \\
\hline IAIN Salatiga & $\underline{\text { https://twitter.com/iain salatiga }}$ & Active \\
\hline IAIN Surakarta & $\underline{\text { https://twitter.com/iainsurakarta }}$ & Active \\
\hline IAIN Pekalongan & $\underline{\text { https://twitter.com/iainpkl }}$ & Active \\
\hline IAIN Kudus & $\underline{\text { https://twitter.com/HumasIAINKudus }}$ & Not active \\
\hline UIN Walisongo & $\underline{\text { https://twitter.com/uinwalisongo }}$ & Not active \\
\hline $\begin{array}{r}\text { Addresses in the table above, all PTKIN have a twitter account. } \\
\text { However, not all actively use it. This makes an impact on the number of } \\
\text { followers. The following data shows it. }\end{array}$
\end{tabular}

Table 11

Number of Followers and Following Twitter on PTKIN

\begin{tabular}{lcc}
\hline \multicolumn{1}{c}{ PTKIN } & Following & Followers \\
\hline IAIN Ponorogo & 14 & 186 \\
\hline IAIN Salatiga & 98 & 1834 \\
\hline IAIN Surakarta & 33 & 3567 \\
\hline IAIN Pekalongan & 10 & 1114 \\
\hline IAIN Kudus & 0 & 0 \\
\hline UIN Walisongo & 0 & 0
\end{tabular}

The number of existing followers is determined by the information provided. The description is as follows:

Table 12

Twitter material on PTKIN

\begin{tabular}{|c|c|c|c|}
\hline \multirow{2}{*}{ PTKIN } & \multicolumn{3}{|c|}{ Twitter material } \\
\hline & Academic Bureaucratic & Speeches of & Quotes for \\
\hline
\end{tabular}




\begin{tabular}{lcccc}
\hline & Activities & Activities & $\begin{array}{c}\text { National } \\
\text { and } \\
\text { Religious } \\
\text { Activities }\end{array}$ & $\begin{array}{c}\text { National } \\
\text { and } \\
\text { Religious } \\
\text { Activities }\end{array}$ \\
\hline IAIN Ponorogo & - & $\mathrm{V}$ & $\mathrm{V}$ & - \\
\hline IAIN Salatiga & $\mathrm{V}$ & - & $\mathrm{V}$ & - \\
\hline IAIN Surakarta & - & - & - & - \\
\hline IAIN & $\mathrm{V}$ & - & - & - \\
Pekalongan & & - & - & - \\
\hline IAIN Kudus & - & - & - & $0 \%$ \\
\hline UIN Walisongo & $\mathrm{V}$ & $16.6 \%$ & $33.3 \%$ & - \\
\hline Percentage & $50 \%$ & - & & - \\
\hline
\end{tabular}

This percentage shows that PTKIN tends to use Twitter for content of academic activities by $50 \%$. The number of followers is not affected by the length of time the institution has joined social media. The following table can be seen below. The use of twitter and blog according to Chawinga's research (2017) is a catalyst for a learner-centered teaching approach because using this technology, it turns out that students are willing and able to share and discuss learning materials, post reflections on their courses and interact among themselves and with their lecturers.

Table 13

Time to Join Twitter on PTKIN

\begin{tabular}{lc}
\hline \multicolumn{1}{c}{ PTKIN } & Joined \\
\hline IAIN Ponorogo & November 2016 \\
\hline IAIN Salatiga & September 2016 \\
\hline IAIN Surakarta & November 2012 \\
\hline IAIN Pekalongan & July 2012 \\
\hline IAIN Kudus & - \\
\hline UIN Walisongo & - \\
\hline
\end{tabular}

The table above shows that the longest joining are IAIN Surakarta and IAIN Pekalongan. Even though there are similarities in the year 2012 it doesn't automatically have the same number of followers. IAIN Surakarta 3000s but only 1000s. Actually, PTKIN can increase the content and the number of 
followers, when actually using it optimally, such as a statement (Smith, 2015) that twitter provides live updates for emergency events or situations, responds to student/student questions quickly, posts timely and relevant news, develops discussions with unique hashtags, and can ask questions and get real-time feedback

\section{Facebook Management}

The six PTKIN studied, all have facebook accounts but not all are active. The following table can be seen.

\section{Table 14}

Facebook Holdings on PTKIN

\begin{tabular}{llc}
\hline \multicolumn{1}{c}{ PTKIN } & \multicolumn{1}{c}{ Facebook } & Information \\
\hline IAIN Ponorogo & $\begin{array}{l}\text { https://web.facebook.com/iain.ponor } \\
\text { ogo.35?_rdc=1\&_rdr }\end{array}$ & Not active \\
\hline IAIN Salatiga & $\begin{array}{l}\text { https://web.facebook.com/iainsalatig } \\
\text { aAKSI/?_rdc=1\&_rdr }\end{array}$ & Active \\
\hline IAIN Surakarta & $\begin{array}{l}\text { https://www.facebook.com/banggaiai } \\
\text { nsurakarta }\end{array}$ & Active \\
\hline IAIN Pekalongan & $\begin{array}{l}\text { https://www.facebook.com/campus.i } \\
\text { ainpekalongan }\end{array}$ & Active \\
\hline IAIN Kudus & & \\
\hline $\begin{array}{l}\text { UIN Walisongo } \\
\text { Semarang }\end{array}$ & $\begin{array}{l}\text { https://web.facebook.com/UIN.walis } \\
\text { ongo.3 }\end{array}$ & Not active \\
\hline $\begin{array}{l}\text { There are two PTKIN who do not actively use their facebook in } \\
\text { displaying the performance of their institution. This has an impact on the } \\
\text { number of followers. The following data shows it. }\end{array}$
\end{tabular}

Table 15

Number of Followers on PTKIN

\begin{tabular}{lc}
\hline \multicolumn{1}{c}{ PTKIN } & Facebook \\
\cline { 2 - 2 } & Friend \\
\hline IAIN Ponorogo & 4953 \\
\hline IAIN Salatiga & 1983 \\
\hline IAIN Surakarta & 882 \\
\hline
\end{tabular}




\begin{tabular}{|c|c|}
\hline IAIN Pekalongan & 7531 \\
\hline IAIN Kudus & - \\
\hline $\begin{array}{ll}\text { UIN } & \text { Walisongo } \\
\text { Semarang } & \end{array}$ & - \\
\hline
\end{tabular}

IAIN Pekalongan has the most number of followers. some of which are determined by the information provided. The description is as follows:

Table 16

Facebook material on PTKIN

\begin{tabular}{lcccc}
\hline \multirow{2}{*}{ PTKIN } & \multicolumn{4}{c}{ Facebook Material } \\
\cline { 2 - 5 } & $\begin{array}{c}\text { Academic } \\
\text { Activities }\end{array}$ & $\begin{array}{c}\text { Bureaucratic } \\
\text { and Non- } \\
\text { Academic } \\
\text { Activities }\end{array}$ & $\begin{array}{c}\text { Speeches } \\
\text { of } \\
\text { National } \\
\text { and } \\
\text { Religious } \\
\text { Activities }\end{array}$ & $\begin{array}{c}\text { Quotes } \\
\text { for } \\
\text { National } \\
\text { and } \\
\text { Religious } \\
\text { Activities }\end{array}$ \\
\hline IAIN Ponorogo & - & $\mathrm{V}$ & $\mathrm{V}$ & - \\
\hline IAIN Salatiga & $\mathrm{V}$ & - & $\mathrm{V}$ & $\mathrm{V}$ \\
\hline IAIN Surakarta & $\mathrm{V}$ & $\mathrm{V}$ & $\mathrm{V}$ & - \\
\hline IAIN & $\mathrm{V}$ & $\mathrm{V}$ & $\mathrm{V}$ & - \\
Pekalongan & - & - & - & - \\
\hline IAIN Kudus & - & - & - & - \\
\hline UIN Walisongo & $50 \%$ & $50 \%$ & $66.6 \%$ & $16.6 \%$ \\
\hline Percentage & & & & \\
\hline
\end{tabular}

PTKIN has not been optimal in strengthening and increasing followers so that it is not able to increase the number of new students. While Facebook has a very large number of users like the statement (Bennett, 2021) that Facebook users are more than 2 billion people per month and more than 1 billion users access the site regularly. YouTube has only 1.5 billion users accessing content, making it the second most popular platform. Interest is in the smallest position of users with 200 million people per month. Other research shows that Facebook is indeed considered an innovative and effective tool in a student-centered learning environment that enriches students' educational experiences, increases the relevance of subject matter and encourages students to collaborate effectively with their peers and lecturers (V.Rasiah, 2014). 
The joining of PTKIN to Facebook is different. Here's the data.

Table 17

Ownership of Instagram on PTKIN

\begin{tabular}{lc}
\hline \multicolumn{1}{c}{ PTKIN } & Joined \\
\hline IAIN Ponorogo & November 2016 \\
\hline IAIN Salatiga & September 2016 \\
\hline IAIN Surakarta & November 2012 \\
\hline IAIN Pekalongan & July 2012 \\
\hline IAIN Kudus & - \\
\hline UIN Walisongo & -
\end{tabular}

The table above shows that the longest joining IAIN Pekalongan and IAIN Surakarta. Even though there are similarities in the year 2012 it doesn't automatically have the same number of followers. IAIN Surakarta has the smallest number of followers compared to 4 PTKIN who are active on social media Facebook. The use of Facebook is not optimal at the existing PTKIN seen from the large number of followers in each institution. This is less profitable when viewed from the findings (Eger et al., 2019:28) which suggests that activity on Facebook can positively enable higher education institutions to communicate better with the public, and thereby achieve one of the main goals of public relations. Effective engagement can also be a trigger to maintain effective Public Relations.

In general, on the content side of each social media consists of: academic activities, bureaucratic and non-academic activities, sayings of national and religious activities, quotes of national and religious activities. This is not profitable because the needs of young people as prospective new students must know more deeply about the institution they are aiming for. Displays on social media at 6 PTKIN are not sufficient to meet the needs of prospective new students. This fact is different from the findings (Chandra \& Andrew, 2019) that the agency's strategy will be optimal when news linearity is maintained, the amount of actual and creative content increases, content reports are updated, and ensures that links and quotes for each content are available. The content in social media 6 PTKIN is still not deep, it needs to be addressed in a way like the findings (Akbar et al., 2018) that information content, events, user guidance, public relations and illustrated writing are content that is more dominant in demand by users than solicitation content, reference services, circulation, and writing. In addition, any social media used by universities has significant 
potential to support learning everywhere (Hashim et al., 2018). The requirements when the content can be a reference for followers must be like opinions (Kirschner et al., 2003:288) that information must be accurate, appropriate and available.

In the context of followers, what needs to be considered for PTKIN, which is still small in number, besides strengthening content, is strengthening the segment which can be based on the experience of universities in the Netherlands, such as the findings (Constantinides \& Stagno, 2011:9-10). The findings show that there are three market segments, namely: Basic Users $(29.5 \%)$ have a low level of participation in online information and social activities. Social Users $(40.7 \%)$ have a high level of participation in social activities and a medium level in information activities. (3) Informational Users $(29.8 \%)$ have a high level of participation in social and information activities.

Overall, the explanation above refers to the opinion of (Khan, 2015:19) the picture is as follows:

\section{Picture}

\section{Social Media Maturity Level}

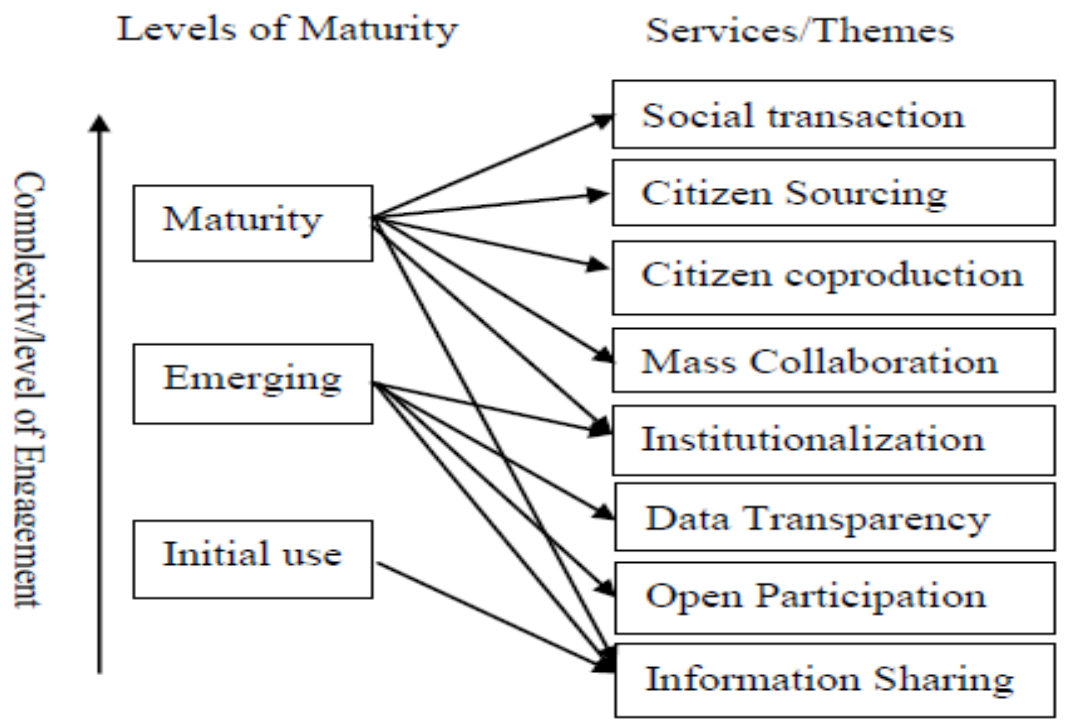

The existing data and based on the picture above shows that PTKIN is still at the initial use level because social media is still information sharing. This condition needs to be improved so that the quality of the institution is getting stronger with stakeholder support through social media. The movement is from 
just information sharing to a higher level both at the emerging level and even more so to the maturity level which requires that the services are institutional and social transactions.

\section{CONCLUSION}

The management of social media is in the Public Relations and Publication sub-section of each PTKI with one admin operating on each social media created. The most followers on Instagram social media are IAIN Salatiga. For social media, YouTube is IAIN Ponorogo, while the most Twitter followers are IAIN Surakarta and the most Facebook followers are IAIN Pekalongan. The use of social media varies, on Instagram for academic activities including promotions for prospective new students dominantly occurs in all research locations and is balanced with greeting content for national and religious activities by $83.3 \%$, for YouTube $66.6 \%$ dominant content of academic activities and this is the same as what happened on twitter, while on social media facebook the percentage is $66,6 \%$ on the content of academic activities and balanced with the content of greeting national and religious activities. The development of social media content lies in quoting national and religious activities. Utilization of social media can be used for all higher education service activities within the scope of the tri dharma of higher education, both the dharma of education/teaching, research and community service.

\section{REFERENCE}

Akbar, M. T., Martutik, M., \& Safii, M. (2018). Konten Akun Media Sosial Twitter Perpustakaan Universitas Perguruan Tinggi Di Indonesia. BIBLIOTIKA: Jurnal Kajian Perpustakaan Dan Informasi, 2(1), 41-49. https://doi.org/10.17977/um008v2i12018p041

Aldahdouh, T. Z., Nokelainen, P., \& Korhonen, V. (2020). Technology and Social Media Usage in Higher Education: The Influence of Individual Innovativeness. SAGE Open, 10(1). https://doi.org/10.1177/2158244019899441

Ansari, J. A. N., \& Khan, N. A. (2020). Exploring the role of social media in collaborative learning the new domain of learning. Smart Learning Environments, 7(1). https://doi.org/10.1186/s40561-020-00118-7

Bado, N., \& Nyangau, J. (2017). Social media and marketing of higher education: A review of the literature. Volume 8, Number 1 Spring 2012 Edited by: Mark van ' t Hooft , Ph . D . Editor Josiah Nyangau Managing Editor. July.

Bennet, J. (2021). 23 Statistik Mengagumkan pada Internet dan Media Sosial di 2021. Wiz Case. https://id.wizcase.com/blog/23-statistik-mengagumkanpada-internet-dan-media-sosial/

Chandra, S., \& Andrew, R. (2019). Peran Media Sosial Dalam Strategi 
Komunikasi Pemasaran Di Sebuah Perguruan Tinggi Swasta Di Jakarta Barat. Jurnal Muara Ilmu Ekonomi Dan Bisnis, 2(2), 521. https://doi.org/10.24912/jmieb.v2i2.2980

Chawinga, W. D. (2017). Taking social media to a university classroom: teaching and learning using Twitter and blogs. International Journal of Educational Technology in Higher Education, 14(1). https://doi.org/10.1186/s41239-0170041-6

Chugh, R. (2020). The Role and Use of Social Media in Higher Education. The Higher Education

Review. https://www.thehighereducationreview.com/opinion/in-my-view/therole-and-use-of-social-media-in-higher-education-fid-38.html

Constantinides, E., \& Stagno, M. C. Z. (2011). Potential of the social media as instruments of higher education marketing: A segmentation study. Journal of Marketing for Higher Education, 21(1), 7-24. https://doi.org/10.1080/08841241.2011.573593

Dan V. Dao. (2015). Social Media Sites Enhance Online Teaching and Learning Activities: Instructors' Perceptions: A Case Study. Journal of Literature and Art Studies, 5(7), 85-94. https://doi.org/10.17265/21595836/2015.07.007

Digital Marketing Instutite Daily Digest. (2020, August 15). The What, Why \& How of Social Media for Higher Education. Digital Marketing Instititute. https://digitalmarketinginstitute.com/blog/what-why-and-how-of-socialmedia-for-higher-education

Duarte, F. (2019, September 9). Berapa banyak waktu yang dihabiskan rakyat Indonesia media di sosial? https://www.bbc.com/indonesia/majalah-49630216

Eger, L., Egerova, D., \& Kryston, M. (2019). Facebook and public relations in higher education. A case study of selected faculties from the Czech Republic and Slovakia. Romanian Journal of Communication and Public Relations, 21(1), 7-30. https://doi.org/10.21018/rjcpr.2019.1.268

Falahah, \& Rosmala, D. (2012). Study of Social Networking usage in Higher Education Environment. Procedia - Social and Behavioral Sciences, 67(November 2011), 156-166. https://doi.org/10.1016/j.sbspro.2012.11.316

Gruzd, A. (2015, August). Current State of Social Media Research: From Practice to Theory \#SMSociety15. Social Media Lab. https://socialmedialab.ca/2015/08/05/current-state-of-social-mediaresearch-from-practice-to-theory-part-1/

Haryanto, A. T. (2019, May 16). Pengguna Internet Indonesia Didominasi Milenial. Detik. https://inet.detik.com/telecommunication/d4551389/pengguna-internet-indonesia-didominasi-milenial 
Hashim, K. F., Rashid, A., \& Atalla, S. (2018). Social media for teaching and learning within higher education institution: A bibliometric analysis of the literature (2008-2018). International Journal of Interactive Mobile Technologies, 12(7), 4-19. https://doi.org/10.3991/ijim.v12i7.9634

HUMAS KEMENPANRB. (2019, July 10). Pemanfaatan Media Sosial untuk Diseminasi Inovasi. Kemenpanrb. https://www.menpan.go.id/site/beritaterkini/pemanfaatan-media-sosial-untuk-diseminasi-inovasi

Iftikhar, M., Riaz, S., \& Yousaf, Z. (2020). Impact of You'Tube Tutorials in Skill Development among University Students of Lahore. Pakistan Journal Of Distance And Online Learning, 5(2), 125-138.

Jackman, W. M. (2019). YouTube usage in the university classroom: An argument for its pedagogical benefits. International Journal of Emerging Technologies in Learning, 14(9), 157-165. https://doi.org/10.3991/IJET.V14I09.10475

Khan, G. F. (2015). Models for Social Media-Based Governments. Asia Pacific Journal of Information Systems, 25(2), 356-369. https://doi.org/10.14329/apjis.2015.25.2.356

Kirschner, P. A., Buckingham Shum, S. J., \& Carr, C. S. (2003). Computer Supported Cooperative $W$ ork.

LLDIKTI V. (2018). Anugerah Humas PTN Dan Kopertis 2017. https://lldikti5.ristekdikti.go.id/home/detailpost/anugerah-humas-ptndan-kopertis-2017

Mardhiyyah, R. (2017). Penggunaan Media Sosial oleb Perguruan Tinggi di Indonesia dan Dampaknya. https://dspace.uii.ac.id/handle/123456789/4761

Maresova, P., \& Hruska, J. (2020). education sciences Social Media University Branding. Education Science, 10(74), 1-14.

Maya Dollarhide. (2021). What Is Social Media. Investopedia. https://www.investopedia.com/terms/s/social-media.asp

Menteri Keuangan. (2019). Kemenkeu. (2019). Peraturan Menteri Peraturan Menteri Keuangan Republik Indonesia Nomor 78 /PMK.02/2019 Tentang Standar Biaya Masukan Tabun Anggaran 2020. Kementerian Keuangan. https://jdih.kemenkeu.go.id/fullText/2019/78 PMK.02 2019Per.pdf

Merriam-Webster. (2021). Social Media. In Merriam-Webster. Merriam-Webster. https://www.merriam-webster.com/dictionary/social media

Motta, J., \& Barbosa, M. (2018). Social Media as a Marketing Tool for European and North American Universities and Colleges. Journal of Intercultural Management, 10(3), 125-154. https://doi.org/10.2478/joim-2018-0020

Parusheva, S., Aleksandrova, Y., \& Hadzhikolev, A. (2018). Use of social media in higher education institutions - an empirical study based on bulgarian learning experience. TEM Journal, 7(1), 171-181. https://doi.org/10.18421/TEM71-21 
Penn, C. S. (2017). How Influence Works: Social Media and the Social Impact Theory. Shift. https://www.shiftcomm.com/insights/social-media-andimpact-theory/

Philip N. Howard; Malcolm R. Parks. (2012). Social Media and Political Change: Capacity, Constraint, and Consequence. Journal of Communication, 62(2), 359-362. https://doi.org/10.1111/j.1460-2466.2012.01626.x

Pratomo, Y. (2019, May 16). APJII: Jumlah Pengguna Internet di Indonesia Tembus 171 Juta Jiwa. Kompas. https://tekno.kompas.com/read/2019/05/16/03260037/apjii-jumlahpengguna-internet-di-indonesia-tembus-171-juta-jiwa.

Republika. (2014, November 28). Perguruan Tinggi Perlu Kelola Media Sosial. Repbulika. https://republika.co.id/berita/pendidikan/duniakampus/nfram6/perguruan-tinggi-perlu-kelola-media-sosial

Reuben, B. R. (2008). The Use of Social Media in Higher Education for Marketing and Communications: A Guide for Professionals in Higher Education. Retrieved from Httpdotedugurn Commpcontentuploads200808socialmediainhighereducation Pdf, 5(Cavazza), 1-13. http://rachelreuben.com/2008/08/social-media-uses-higher-educationmarketing-communication/

Sehl, K. (2020, August). Social Media in Higher Education: 8 Essential Tips. Hootsuite. https://blog.hootsuite.com/social-media-in-higher-education/

Smith, R. (2015). The Role of Social Media in Higher Education Marketing. Boston Digital. https://www.bostondigital.com/insights/role-social-mediahigher-education-marketing

Unimalnews. (2019, October 31). Media Sosial untuk Peningkatan Kinerja Humas Universitas. Unimal. https://news.unimal.ac.id/index/single/764/media-sosial-untukpeningkatan-kinerja-humas-universitas

UNY. (2019). Perlu, Branding Perguruan Tinggi Melalui Media Sosial. UNY. https://www.uny.ac.id/berita/perlu-branding-perguruan-tinggi-melaluimedia-sosial

V.Rasiah, R. R. (2014). Transformative Higher Education Teaching and Learning: Using Social Media in a Team-based Learning Environment. Procedia - Social and Behavioral Sciences, 123(2012), 369-379. https://doi.org/10.1016/j.sbspro.2014.01.1435

Vivakaran, M. V., \& Neelamalar, M. (2018). Utilization of Social Media Platforms for Educational Purposes among the Faculty of Higher Education with Special Reference to Tamil Nadu. Higher Education for the Future, 5(1), 4-19. https://doi.org/10.1177/2347631117738638 